Małgorzata Gutry-Korycka

\title{
MATHEMATICAL-PHYSICAL MODEL OF INTERCEPTION PROCESS IN THE PLANT COVER
}

From the point of view of interception of the plant canopy it is necessary to separate natural phytocenoses, i.e. homogenous patches of plant communities and agrocenoses with considerably high degree of biocenosis stability in individual vegetation seasons.

Identification of the structure of quasi-homogenous fields, their quality (kind) and spatial range from the point of view of interception process of plant cover is the first step in the identification procedure. Modern teledetection and photogrammetric techniques that enable one to obtain single and repetitive pictures being a basis for interpreting the surface structure, are decisive as far as the quality and possibilities of transforming spatial information are concerned. It is necessary to remember, however, that modern techniques of information transformation cannot be utilized without repair ground studies; they increase, however, the speed of obtaining spatial-time information and are decisive with reference to its high quality and accuracy.

STRUCTURE OF MATHEMATICAL MODEL OF THE INTERCEPTION PROCESS

The starting point for the analysis of the interception process is a homogenous patch of vegetation, phytocenosis being a basic spatial unit for modelling the interception process. Phytocenoses have their peculiar features, such as floristic composition, i.e. a list of species on the pattern surface and population structure of the vegetation (Kersha'w, 1978).

The experimental works conducted so far have confirmed not only the influence of floristic composition, but also the age, the population structure and the state of vegetative development of the flora on formation of individual phases of retaining and trickling of the precipitation. Only going deeply into the physics of the processes of energy and mass exchange in the vegetation layer gave positive results in the stu- 
dies on interception. Theoretical bases permiting recogniton of the physics of the process were formulated by Horton, Linsley and Meriam (Grey, 1973) and developed by others including Leanard (1967), Zinke (1967), Rutter with a team (1972), Bultot with a team (1972) and Blake (1975).

Considering the above remarks it appears that the structure of mathematical model of interception should result from the kind of phytocenosis and parameters of the vegetation structure. A mojority of forest communities in Poland have a four-fold character as they are composed of four main layers mutually intermingling. An optimum model of interception in forest phytocenoses is a layer model which can be treated doubly: as a subsystem separate in each layer or as an integral system. Such an approach enables one to treat a unit like a forest phytocenosis in four layers and an agrocenosis in one layer. An inspirational role in preparing a structure of the interception model was played by Harris's (1972) simulation model of moistening tree trunks at various altitudes and Fleming's (1975) model of interception.

There exists a considerable similarity of the chosen models with reference to the mathematical approach based on dynamic equations of water balance of the vegetation layer considering its population characteristics. Some of the parameters are invariable in time, others are discreetly spread in time. The above-mentioned parameters have a physical sense and the functions contained in the structure of the model are based on physical grounds. Figure 1 presents a suggestion of the model structure in such an approach. A universal algorithm of calculations, taking into account the dynamic form of the water balance equation of the vegetation layer (equation 1) in proposed by Fleming (1975). This equation can be used in any time interval $\Delta t$ and in any unit vegetation community. In the proposed layer model the algorithm of Fleming's calculation was preserved. The introduced changes concerned Jimitations of invariability of the parameters connected with the charactristics of the vegetation layer in individual layers and the ones connected with the development of their vegetative phases. The input to the model is atmospheric precipitation onto the surface of tree tops or plantations, and the output from all the layers is the precipitation reaching the soil.

In Fleming's model the input is a ratio of precipitation onto vegetation $(P)$ and the density of vegetation $\left(D_{c}\right)$. Respectively, the precipitation penetrating directly between the tree tops or other plants is treated as value $P\left(1-D_{c_{1}}\right)$. In the second layer of the subsystem the input is defined as a ratio of precipitation $(P)$ and density of bushes $\left(D_{c_{2}}\right)$, in 
the third it is a ratio of $(\mathrm{P})$ and density of green plants, grass or brushwood $\left(\mathrm{D}_{\mathrm{c}_{3}}\right)$. And in the fourth layer the precipitation is a ratio of (P) and density of moss, over-growth, mushrooms and litter cover $\left(\mathrm{D}_{\mathrm{c}_{4}}\right)$. The British model assumes density of vegetation cover $\left(D_{c}\right)$ as a parameter invariable in time.

In the light of experimental measurements of interception such a limitation seems to be too general; It may refer exclusively to trees and coniferous bushes (without the larch) with a permanent litter of conifer needles during the year (Gutry-Korycka, 1980). Deciduous trees and bushes as well as herbaceous plants, grass and brush-wood and also plantations change in a significant way density in individual phases of vegetative development, dependent on foliage. The most important parameter of precipitation transformation in the vegetation cover is a maximum storage capacity of interception $\left(S i_{\max }\right)$. This value is treated by Fleming as a. maximum capacity of the reservoir characterizing a given type of vegetation $\left(S i_{\max }\right)$ which should be accepted a priori. In the storey model it is necessary, to determine $\left(S i_{\max }\right)$ separately for each layer of the vegetation, assuming different capacity of each of them, respectively $S i_{1 \max }, S i_{2 \max }, S i_{3 \max }, S i_{4 \max }$. Changes of interception storage $\Delta S i_{\mathrm{n}}(\mathrm{mm})$ on a unit vegetation area are the function of time and $S i_{\max }$. Excess water passing through the interception process of the vegetation cover is determined in ( $\mathrm{mm})$. Changes of interception in time can be determined by means of a simple equation

$$
\Delta S i=\left(P \times D_{c}\right)-E
$$

where: $E-$ value of potential evaporation $(\mathrm{mm})$. Trickling of water from the vegetation cover $(\mathrm{T})$ is treated as excessive storage of interception and is calculated according to the following equation in absolute values,

$$
T=\left|\left(S i_{n(\mathrm{t}-1)}+\Delta S i_{(\mathrm{t})}\right)-S i_{\max }\right|
$$

where:

$T$ - trickling of water from plants defined as excessive storage capacity of interception,

$S i_{\mathrm{n}}$ - interception storage in time $(t-1)$,

$\Delta S i$ - increase of interception storage in time $t$, $S i_{\max }$ - maximum storage capacity of interception.

This equation should be treated in a conditional form (for one layer)

$$
T=\left\{\begin{array}{cl}
S i_{\mathrm{n}(\mathrm{t}-1)}+\Delta S i_{(\mathrm{t})}-S i_{\max } \\
0
\end{array}\right\} \text { when } \begin{array}{ll}
\left(S i_{\mathrm{n}(\mathrm{t}-1)}+\Delta S i_{(\mathrm{t})}\right)>S i_{\max } \\
\\
\left(S i_{\mathrm{n}(\mathrm{t}-1)}+\Delta S i_{(\mathrm{t})}\right) \leqslant S i_{\max }
\end{array}
$$


Maximum storage capacity of interception is a characteristic feature of the above-mentioned vegetation communities and is equal to the total of storage capacities of interception of all the individual layers. Considering such and approach, the total precipitation onto the soil surface covered by vegetation can be determined from the following equation:

$$
\operatorname{Pgr}=P\left(1-\sum_{\mathrm{i}=1}^{\mathrm{i}=4} D c_{\mathrm{i}}\right)+\sum_{\mathrm{i}=1}^{\mathrm{i}=4} T_{\mathrm{i}}
$$

whereas:

$$
D c_{1}+D c_{2}+D c_{3}+D c_{4}+D c_{o}=1
$$

where: $D c_{1}, D c_{2}, D c_{3}, D c_{4}$ - density in individual layers

$$
D c_{\circ}=1-\sum_{1}^{\mathrm{n}} D c_{\mathrm{i}}
$$

The structure of the model is simple and quite universal, and it can be used in any arrangement of natural and cultivated vegetation; besides, other characteristics of the vegetation populations can be introduced, e.g. thickness of plants or foliage.

\section{POPULATION PARAMETERS OF VEGETATION COMMUNITIES}

Although the metods of determining numerical population characteristics of the vegetation cover depend on the kind of vegetation, they have visible common features that consist in estimation of density, thickness, or extent to which the soil is covered by vegetation. Experimental measurement techniques used in forests and agrocenoses are based on direct readings of the characteristics from the structure of density in an airplane photograph; more often, however, they are obtained through dendrometric or phytomorphological ground measurements. Photogrammetric pictures enable one to determine the view of tree crowns on the earth surface and their total area is calculated; besides, special ground pictures allow one to determine the degree of sky clearance (the horizon) between the trees. Photographing from a tripod is of great help here and a special preparation of the contrast between the clear area and the cultivated crops allows one to estimate their thickness. Most often, however, in order to determine the degree of covering the soil by foliage, the method called point-square described by Toebes and Ouryvaev (1970) and Kolodziej, Orzeł (1978) is used. Dendrometric measurements in forests and bushes are done directly and although they are often arduous and not very precise, they still are the basis for identifying 
the population parameters. In the case of deciduous vegetation (trees and cultivation) in place of density of thickness, often parameters connected with foliage are used which determine directly the interception area changing in imperceptible time intervals. Then the parameter called LAI (Leaf Area Index) is used, or in other words the lamina index. It is also determined experimentally by planimetering all the leaves on a model area (with the help of a planimeter or automatically by reading the size of projection of the leaves on an electronic screen) which is utilized by Orzel (1980). The ratio of the leaves surface to the soil area is the LAI index.

\section{MAXIMUM STORAGE CAPACITY OF INTERCEPTION OF VEGETATION COVER}

There exist various approaches in order to estimate $\mathrm{Si}_{\max }$ which is the most important parameter. Most common is a direct measurement of the process of retaining the precipitation by vegetation cover done with the help of pluviometers placed on various levels of the forest ceiling. Comparative pluviographic methods are used here that enable one to define differenoes between the precipitation at the level of vegetation and the precipitation onto the earth surface under the canopy of tree tops. Different kinds of measurement combinations are used here (drains, sealing the bedding, bands on tree trunks) (Osuch 1981, Borman and Likens 1979).

More and more often laboratory experiments substitute direct measurements. They are made in a phytothrone which permits a simulation of the process of retaining the precipitation by vegetation in an artificial way. Such a simultation of moistening, for instance, a trunk was done by Borman and Likens (1979), and Poskuta with a team made it with selected cultivated plants $(1980,1981)$.

A completely different method to identify the parameters is estimating $\mathrm{Si}_{\max }$ as a function of phytomass of fresh plants. This requires other measurement techniques which are based on physical determination of the weight by weighing overground portions of plants: twigs, leaves, flowers, cones and now shoots. As shown by experiments made by Jagtenberg (1962) and confirmed by Poskuta from the University of Warsaw $(1980,1981)$ on grass agrocenoses and main plants cultivated in Foland, half of the biomass weight can be identified with storage capacity of those plants. Comparative studies proved that $\mathrm{Si}_{\max }$ of deciduous and coniferous trees is close to the capacity of the tree crowns in the phase of full vegetative development. 


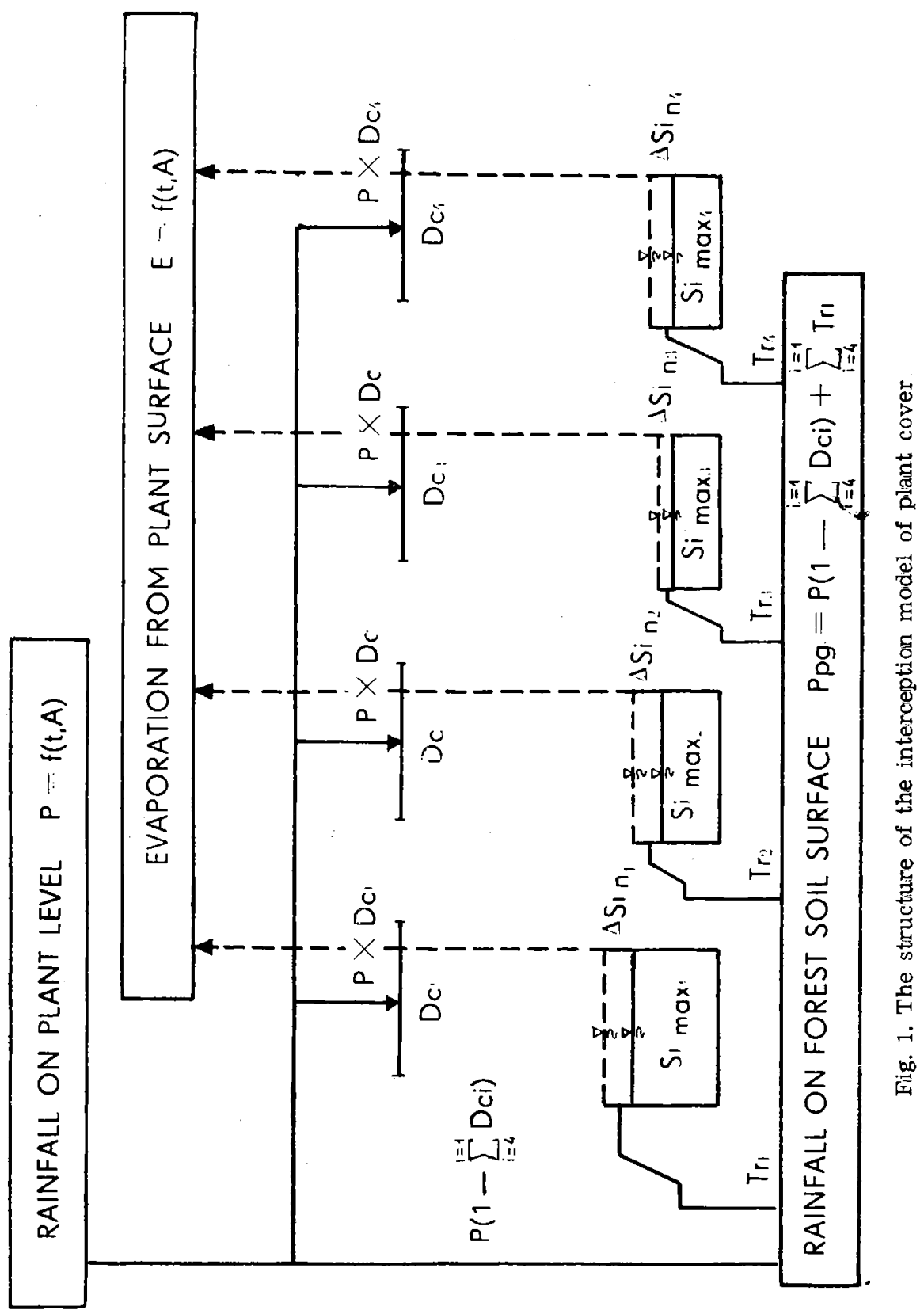


To estimate the biomass of stands of trees in experimental conditions is an exacting and difficult task. That is why model dendrometric measurements are made to estimate the biomass with regard to the age and height of the trees as well as their breast height diameter by various varieties (Assmann, 1968; Vyskot, 1981).

\section{REFERENCES}

Assman, E., Nauka o produkcji lasu (The Science of the Productivity of Forest), PWRiL, Warszawa 1968.

B la ke, G.J., The Interception Process, Symposium on Hydrology (Eds. Chapman T. G., Dunin F.X.), Australia 1975.

B ormann, F. H., Likens, G. E., Pattern and Process in a Forested Ecosystcm. Springer-Verlag, New York Inc., 1979.

Bultot, F., Dupriez, G. L., Bodeux, A., "Interception de la pluie par le végétation forestière: estimation le l'interception journalière à l'aide d'un model mathématique", J. Hydrol. 17-1972.

Fleming, G., Computer Simulation Techniques in Hydrology, Elsevier, New York-Oxford-Amsterdam 1975.

Gray, M., Handbook on the Principles of Hydrology, Water Information Center Publications, 1973.

Gutry-Korycka, M., "Matematyczno-fizyczne aspekty procesu intercepcji szaty roślinnej" (Mathematical and Physical Aspects of the Process of Interception in Plant Cover), Przeglad Geofizyczny, No. 2, 1980.

$\mathrm{Har} \mathrm{r}$ is, G.P., "The ecology of corticolous lichens. IIr. A. Simulation model of productivity as a function of light intensity and water availability", Journal of Ecology, Viol. 60, 1972.

J a g t e $\mathrm{n}$ b e r g, W. D., Droge-stofgehalten van gras Meded. 62. Proefstation voor de Akker - $\mathrm{n}$ Weidebouw, Wageningen 1962.

$\mathrm{K}$ ers haw, K. A., Ilościowa $i$ dynamiczna ekologia roślin, (Quantitative and dynanamic plant ecology), PWN, Warszawa 1978.

Kolodziej, J., Orzel, W. 1978: "Badania nad metodyką pomiaru intercepcj: cpadowej w lamie roślin uprawnych" (Studies on the Methodology of Measurement of Rainfall Interception in the Cornfield of Cultivated Plants) Folia Societatis Scientriarum Lublinensis Vol. 20, Geogr. 2.

Leonard, R.E., "Mathematical Theory of Interception", International Symposium on Forest Hydrology of Pennsylvania University, Pergamon Press, New York 1967.

Orze1, W., Intercepcja opadowa wybranych roślin uprawnych. (Rainfall Interception of Some Selected Cultivated Plants), doctoral dissertation, typescript WSR Lublin 1980.

Os u ch, B. et. al., "Wyniki pomiarów intercepcji szaty roślinnej" (Results of Measurements of Interception of Plant Cover) Archiwum UW 1981.

Poskuta, J., "Doświadczenia nad intercepcją szaty roślin uprawnych" (Experiments on the interception of the plant cover of cultivated plants. Archiwum $U W$, (prace PR7), 1981.

Rutter, A.J., Kershaw, K. A., Robins, P.C., Morton, A.J., "A predicative mode1 of rainfall interception", Agricultural Meteorology 9, 5/6, 1972. 
T o e bes, C., O u ryva v, V., Representative and experimental basins, UNESCO. Paris 1970.

$\mathrm{Z}$ in ke, P. J., Forest Interception Studies in the United States, International Symposium on Forest Hydrology, Pergamon Press, New York 1967.

Vyskot, M., Biomass of the Layer of a Spruce Forest in the Bohemian Uplands, The Publishing House of the Chechoslovak Academy of Sciences, Praha 1981. 